\title{
Radial oxygen loss has different effects on the accumulation of total mercury and methylmercury in rice
}

\author{
Xun Wang • Bing Li • Nora Fung-Yee Tam • \\ Lu Huang • Xiaoli Qi • Hongbin Wang • Zhihong Ye • \\ Mei Meng • Jianbo Shi
}

Received: 5 August 2014 / Accepted: 12 August 2014 / Published online: 20 August 2014

(C) Springer International Publishing Switzerland 2014

\begin{abstract}
Background and Aims Mercury (Hg) pollution in paddy fields and rice has aroused great concern in recent years. This study investigated the dynamic changes of radial oxygen loss (ROL) and Fe plaque formation on roots, and their effects on $\mathrm{Hg}$ accumulation in rice plants.

Methods A rhizobag experiment was conducted to study temporal variations and correlations between ROL (amounts and rates), Fe plaque formation, total $\mathrm{Hg}$ ( $\mathrm{THg}$ ) and methylmercury $(\mathrm{MeHg})$ in plant tissues and in plaque of four rice cultivars during six growth stages.
\end{abstract}

Responsible Editor: Henk Schat.

Xun Wang and Bing Li the authors equal contribution to this work.

Electronic supplementary material The online version of this article (doi:10.1007/s11104-014-2239-x) contains supplementary material, which is available to authorized users.

X. Wang $\cdot$ L. Huang $\cdot$ X. Qi $\cdot$ Z. Ye $(\bowtie)$

State Key Laboratory of Biocontrol and Guangdong Key

Laboratory of Plant Resources, School of Life Sciences,

Sun Yat-sen University, Guangzhou 510006,

People's Republic of China

e-mail: 1ssyzhh@mail.sysu.edu.cn

B. $\mathrm{Li}$

Ecological Civilization Construction Committee of Guiyang, Guiyang Research Academy of Eco-Environmental Sciences, Guiyang 550002, People's Republic of China

\section{N. F.-Y. Tam}

Department of Biology and Chemistry, City University of Hong Kong, Kowloon, Hong Kong SAR,

People's Republic of China
Results ROL amounts and Fe plaque formation increased from tillering to reproductive stages, then ROL amounts gradually decreased until maturation stage, whereas Fe plaque remained relatively stable. ROL rates continued to decline during the entire growth period. Both ROL amounts and $\mathrm{Fe}$ concentrations in plaque were positively correlated with $\mathrm{THg}$ concentrations in the plaque, whereas negatively correlated with $\mathrm{THg}$ in straw and brown rice. However, there were no significant relationships between $\mathrm{ROL}, \mathrm{Fe}$ in plaque and $\mathrm{MeHg}$ in plaque and in plant tissues. 
Conclusions ROL has great effects on THg but not $\mathrm{MeHg}$ accumulation in rice plants. Rice cultivars with higher ROLs tend to have a greater ability to reduce $\mathrm{THg}$ accumulation in brown rice.

Keywords Dynamic changes · Iron plaque · Mercury · Methylmercury · Oryza sativa L · Radial oxygen loss (ROL)

\section{Introduction}

Mercury $(\mathrm{Hg})$ is now recognized as a global contaminant which is extremely toxic (Jiang et al. 2006). Methylmercury $(\mathrm{MeHg})$, the most common form of organic $\mathrm{Hg}$, is of greater concern due to its higher toxicity for humans and its ability to be more readily bioaccumulated and biomagnified along food chains (Ullrich et al. 2001). It is generally considered that the consumption of marine products such as fish and shellfish is a major pathway of human exposure to $\mathrm{MeHg}$ (Clarkson 1993). However, recent studies have shown that rice (Oryza sativa L.), a staple food in Asia, can be another primary source of $\mathrm{MeHg}$ for humans, particularly in $\mathrm{Hg}$ mining areas and also in certain inland areas in Southwestern China (Feng et al. 2008; Li et al. 2008; Zhang et al. 2010a, b). Therefore, minimizing grain $\mathrm{Hg}$ and $\mathrm{MeHg}$ in rice production, especially in $\mathrm{Hg}$ contaminated regions, is of great importance.

To adapt to anaerobic conditions, wetland plants such as rice develop aerenchyma to transfer $\mathrm{O}_{2}$ from the aerial parts to the roots, resulting in $\mathrm{O}_{2}$ diffusing toward the root apex and its rhizosphere - a process which is termed radial oxygen loss (ROL) (Colmer 2003). ROL can create an oxidizing environment in the rhizosphere and cause precipitation of toxic metals onto the rhizosphere soil and root surfaces (Otte et al. 1989). Previous studies have indicated that rice cultivars with higher rates of ROL possess greater capacities for limiting the transfer of cadmium (Cd) and arsenic (As) to aboveground tissues (Mei et al. 2009, 2012; Wang et al. 2011). Due to the ROL from plants and biological oxidation by microorganisms, substantial quantities of iron $(\mathrm{Fe})$ are transferred to the plaque, leading to a well-defined zone of ferric oxydroxide accumulation (Taylor et al. 1984; Macfie and Crowder 1987). Fe plaque is able to sequester metal(loid)s by adsorption and/or co-precipitation, thus affecting the bioavailability of these elements in the rhizosphere, which can influence metal tolerance and uptake by wetland plants (Otte et al. 1989; Ye et al. 1997; Blute et al. 2004). Hansel et al. (2001) found that Fe plaque formation could reduce lead $(\mathrm{Pb})$ and zinc ( $\mathrm{Zn})$ uptake and translocation in the wetland grass Phalaris arundinacea. The formation of Fe plaque on roots significantly inhibited the uptake of As by rice, under both glasshouse (Chen et al. 2005) and paddy field conditions (Garnier et al. 2010). It has also been reported that adding ferrous iron to sulphidic wetland sediments decreased $\mathrm{Hg}$ bioavailability and net methylation due to a decrease in sulphide activity and a concomitant decrease in the concentration of dissolved mercury (Mehrotra et al. 2003; Mehrotra and Sedlak 2005). However, the exact effects of ROL and Fe plaque formation on $\mathrm{Hg}$ and $\mathrm{MeHg}$ uptake by rice plants have not been reported.

It is notable that the $\mathrm{ROL}$ and $\mathrm{Fe}$ plaque of rice roots could change in amount and composition during growth (Nanzyo et al. 2010; Wang et al. 2013). Wang et al. (2013) reported that amount of ROL per plant and Fe plaque increased dramatically from tillering to ear emergence stages and then decreased at the grain-filling stage. Nanzyo et al. (2010) found that the quantity of root $\mathrm{Fe}$ plaque reached its peak at the tillering stage, after which it gradually decreased. Furthermore, dissolved organic matter (DOM) secreted by roots might influence the formation of Fe plaque since DOM could provide protons and electrons for reductive dissolution of Fe plaque (Zhang et al. 2012). Aulakh et al. (2001) reported that the level of DOM changed during the entire growth period, reaching its peak in the earing and flowering stage and then gradually decreased. The results from the above previous studies suggest that changes in ROL and $\mathrm{Fe}$ plaque during the growth period of rice plants may also have great effects on $\mathrm{THg} / \mathrm{MeHg}$ uptake and accumulation. However, little information is available on the effects of the dynamic changes of ROL and $\mathrm{Fe}$ plaque on the accumulation and distribution of $\mathrm{Hg}$ and $\mathrm{MeHg}$ in rice plants and other wetland plants. The study therefore aims to investigate the dynamic changes of ROL and Fe plaque formation and temporal variations in $\mathrm{Hg}$ and $\mathrm{MeHg}$ accumulation and distribution in rice plants at six definable growth stages (tillering, elongation, ear emergence, flowering, grain-filling and maturation) and their relationships, and so reveal the potential roles of $\mathrm{ROL}$ and $\mathrm{Fe}$ plaque on $\mathrm{Hg}$ and $\mathrm{MeHg}$ uptake by rice plants. 


\section{Materials and methods}

Pre-culture of rice seedlings

Two indica rice cultivars, Tianyou196 (TY196) and Huayouguangkangzhan (HY) and two japonica cultivars, Nanjing 35 (NJ35) and Zixiangnuo (ZX), were selected due to their differences in $\mathrm{Hg}$ accumulation properties according to our previous study ( $\mathrm{Li}$ et al. 2013). The two cultivars, TY196 (22.8土 $\left.0.7 \mathrm{ng} \mathrm{g}^{-1} \mathrm{THg}\right)$ and NJ35 (20.5 $\pm 2.7 \mathrm{ng} \mathrm{g}^{-1}$ $\mathrm{THg}$ ), have a lower $\mathrm{Hg}$ accumulation in brown rice than that in the other two cultivars, HY $\left(30.1 \pm 3.1 \mathrm{ng} \mathrm{g}^{-1} \mathrm{THg}\right)$ and $\mathrm{ZX}\left(28.5 \pm 2.2 \mathrm{ng} \mathrm{g}^{-1}\right.$ $\mathrm{THg}$ ). Seeds were surface sterilized with $30 \% \mathrm{v} / \mathrm{v}$ hydrogen peroxide $\left(\mathrm{H}_{2} \mathrm{O}_{2}\right)$ for $30 \mathrm{~min}$ and washed thoroughly with deionized water. They were then germinated in acid-washed quartz sand and distilled water was used to moisten the seeds and to irrigate the germinated seedlings for 7 days. Seedlings were subsequently transferred to plastic containers (12 L, 80-100 seedlings per container) and grown in 1/4-strength solution for 25 days with the following nutrient composition $\left(\mu \mathrm{mol} \mathrm{L} \mathrm{L}^{-1}\right)$ : $\mathrm{NH}_{4} \mathrm{NO}_{3} 500, \mathrm{~K}_{2} \mathrm{SO}_{4}$ 200, $\mathrm{CaCl}_{2}$ 400, $\mathrm{MgSO}_{4}$. $7 \mathrm{H}_{2} \mathrm{O}$ 1500, $\mathrm{KH}_{2} \mathrm{PO}_{4}$ 1.3, Fe-EDTA 50, $\mathrm{H}_{3} \mathrm{BO}_{3}$ $10, \mathrm{ZnSO}_{4} \cdot 7 \mathrm{H}_{2} \mathrm{O} 1.0, \mathrm{CuSO}_{4} \cdot 5 \mathrm{H}_{2} \mathrm{O} 1.0, \mathrm{MnSO}_{4}$. $5 \mathrm{H}_{2} \mathrm{O} 5.0, \mathrm{Na}_{2} \mathrm{MoO}_{4} \cdot 2 \mathrm{H}_{2} \mathrm{O} 0.5$ and $\mathrm{CoSO}_{4} \cdot 7 \mathrm{H}_{2} \mathrm{O}$ 0.25 . The nutrient solution was left without any forced aeration, adjusted to $\mathrm{pH} 6.0$ with $\mathrm{NaOH}$ or $\mathrm{HCl}$ and changed every 5 days.

Pot experiment under waterlogged conditions

Soil was collected from the plough layer $(0-20 \mathrm{~cm})$ of a paddy field, located in Wanshan $\mathrm{Hg}$ mining area in Guizhou Province, Southwest China. The soil pH (measured in the water extract following the method of ISO 10390: 2005) was 7.0, and the soil contained $2.34 \%$ total C (Total Organic Carbon Analyzer, Shimadzu, Japan), $0.14 \%$ total N (Automated Discrete Analyzer, SmartChem 200, Alliance, France), $46 \mu \mathrm{g} \mathrm{g}^{-1} \mathrm{THg}$ and $3.7 \mathrm{ng} \mathrm{g}^{-1} \mathrm{MeHg}$ (following method of USEPA 1630: 2001). After being air-dried, sieved to $<10$ mesh and homogenization, soil was supplemented with basal fertilizers [125 mg N kg${ }^{-1}$ soil as $\left(\mathrm{NH}_{2}\right)_{2} \mathrm{CO}, 80 \mathrm{mg} \mathrm{P} \mathrm{kg}^{-1}$ and $125 \mathrm{mg} \mathrm{K} \mathrm{kg}^{-1}$ soil as $\mathrm{KH}_{2} \mathrm{PO}_{4}$ and $\left.\mathrm{K}_{2} \mathrm{SO}_{4}\right]$, mixed thoroughly and equilibrated for a month. A cylindrical nylon rhizobag (30 $\mu \mathrm{m}$ nylon mesh, $8 \mathrm{~cm}$ diameter and
$11 \mathrm{~cm}$ length) was designed to separate rhizosphere from non-rhizosphere zones. The rhizobag, which was separated longitudinally into two halves by a thin plastic card in the centre and filled with $500 \mathrm{~g}$ dry sand (the same acid-washed quartz sand as that used at the germination stage), was then placed in the centre of a PVC pot $(14 \mathrm{~cm}$ diameter and $18 \mathrm{~cm}$ high), filled with $1.5 \mathrm{~kg}$ paddy soil (Cheng et al. 2014). The system was inundated with $2 \mathrm{~cm}$ water above the soil surface for 2 weeks before planting.

Rice seedlings were carefully transplanted into the rhizobags, with two seedlings in each rhizobag, one each side of the central separator. There were 4 replicates per treatment. Soil in each pot was kept submerged using deionized water and the seedlings were grown in a glasshouse with the following conditions: temperatures day/night were $25 / 20^{\circ} \mathrm{C}$, day/night relatively humidity was $60 / 80 \%$ and $16 \mathrm{~h}$ of light with a $>350 \mu \mathrm{mol} \mathrm{m}^{-2} \mathrm{~s}^{-1}$ photon flux density.

Harvest and sampling

After transplanting, plants were harvested at their tillering stage (the stage when side shoots are produced, day 26), elongation stage (when rice plants grow at their fastest rate, and stems are elongating, day 42), ear emergence stage (when developing ears are visible, day 59), flowering stage (when most ears are flowering, day 72), grain-filling stage (when grains are being filled, day 85) and maturation stage (when grains are ripe, day 101), respectively. The two plants from a pot were separated and washed thoroughly with deionized water. One plant was used for determining the ROL and the other for DCB extraction of $\mathrm{Fe}$ plaque on root surfaces. After Fe plaque was extracted, the plants were separated into roots (all stages), straw (a mixture of stems and leaves in all stages), panicle (flowering stage), grains (grain-filling stage), husk and brown rice (maturation stage). All the harvested plant samples were freeze-dried and the freezedried weight was measured. The samples were then ground to a fine powder and stored at $4{ }^{\circ} \mathrm{C}$ for further analysis.

ROL measurement

ROL amounts were measured using a titanium(III) citrate buffer method (Kludze et al. 1994). The 
actual ROL amount was calculated using the following formula:

ROL amount $=\mathrm{c}(\mathrm{y}-\mathrm{z})$

Rate of ROL $=\mathrm{c}(\mathrm{y}-\mathrm{z}) / \mathrm{g}$

where ROL is measured as $\mu \mathrm{mol} \mathrm{O} \mathrm{O}_{2}$ plant $^{-1} \mathrm{~h}^{-1}$, $\mathbf{c}$ is the initial volume of $\mathrm{Ti}^{3+}$ added to each tube (in L), $\mathbf{y}$ is the concentration of $\mathrm{Ti}^{3+}$ in the solution of the control (without plants) (in $\mu \mathrm{mol} \mathrm{Ti}{ }^{3+} \mathrm{L}^{-1}$ ), $\mathbf{z}$ is the concentration of $\mathrm{Ti}^{3+}$ in solution after $6 \mathrm{~h}$ treatment with plants (in $\mu \mathrm{mol} \mathrm{Ti}{ }^{3+}$ in solution plant ${ }^{-1} \mathrm{~L}^{-1}$ ), and $\mathbf{g}$ is the root dry weight (in $\mathrm{kg}$ ).

\section{DCB extraction of Fe plaque}

Iron plaque on fresh root surfaces of rice plants was extracted using the dithionite-citrate-bicarbonate (DCB) method (Otte et al. 1989). The whole root system from each plant was harvested for the DCB extraction and the dry weight of root was measured after extraction. The roots were washed twice with deionized water and then incubated for $60 \mathrm{~min}$ in $40 \mathrm{ml}$ cold solution of dithionite-citrate-bicarbonate $(0.03 \mathrm{M}$ sodium citrate and $0.125 \mathrm{M}$ sodium bicarbonate with the addition of $0.6 \mathrm{~g}$ sodium dithionite). After incubation, roots were rinsed three times with deionized water and the rinsings added to the DCB extract. The resulting solution was made up to $100 \mathrm{ml}$ with deionized water for analysis. Since it is hard to obtain the exact mass of plaque, the comparison of the Fe plaque formation on root surfaces between treatments was based on the 'per gram of root dry weight'. Such expression has been widely used in similar studies in wetland plants (Taylor and Crowder 1983; Otte et al. 1989; Ye et al. 1997).

Sample analysis

Concentrations of THg and Fe in DCB-extracted solutions were determined by Atomic Absorption Spectroscopy (AAS, Z-5000, Hitachi, Japan) (for THg) and Inductively-Coupled Plasma Optical Emission Spectrometry (ICP-OES, Optima 2000 DV, Perkin Elmer, USA) (for Fe), respectively. The plant samples were ground to a fine powder and mixed completely. Then $0.2 \mathrm{~g}$ was randomly collected from each sample and microwave-digested in concentrated $\mathrm{HNO}_{3}(16 \mathrm{~mol}$ $\mathrm{L}^{-1}$ ) and $\mathrm{THg}$ in the digests measured by atomic fluorescence spectrometry (AFS, Beijing Titan Instrument Co., Ltd). For MeHg analysis, plant samples ( $0.2 \mathrm{~g}$, the same as above) were prepared by $\mathrm{KOH}-$ methanol/solvent extraction and determined with a MERX Automatic Methylmercury System (Brooks Rand Laboratories, Seattle, WA), following method 1630 (USEPA 2001). Blanks, tea standard material (GBW-08303) (China Standard Materials Research Center, Beijing, P.R. China), lobster standard material (TORT-2) (National Research Council of Canada) were used for quality control. Recoveries from the reference materials and matrix spikes ranged from 95 to $102 \%$ for THg analysis, 97 to $104 \%$ for Fe analysis, and from 86 to $104 \%$ for $\mathrm{MeHg}$ analysis.

Statistical analysis

Data were analyzed using the statistical software package SPSS 17.0 and summarized by means \pm standard errors (SE). Means were compared by least significant difference (LSD) at the $5 \%$ level. Coefficients of determination $\left(\mathrm{R}^{2}\right)$ and significance probabilities $(\mathrm{P})$ were computed for linear regression fits.

\section{Results}

Growth, ROL and Fe plaque formation

The biomass of roots and straw tissues of the four rice cultivars at six growth stages are listed in Table 1. They both increased significantly during the entire growth period and at the same growth stage, significant differences $(P<0.05)$ were detected among the cultivars. Both amounts and rates of radial oxygen loss (ROL) were significantly different $(P<0.01)$ between the growth stages, ranging on average from 1.2 to $16 \mu \mathrm{mol} \mathrm{O}$ plant ${ }^{-1} \mathrm{~h}^{-1}$ and from 0.42 to $14 \mathrm{mmol} \mathrm{O}_{2} \mathrm{~kg}^{-1}$ root d.w. $\mathrm{h}^{-1}$, respectively. The dynamic changes of ROL amounts followed this trend: increasing from tillering stage to reproductive stage, then decreasing gradually to the maturation stage (Fig. 1a). However, ROL rates gradually declined down as rice plants grew from tillering stage to maturation stage (Fig. 1b). Additionally, significant differences $(P<0.05)$ in both amounts and rates of ROL were detected among the rice cultivars at the same growth stage, following the trend: NJ35 > TY196 > HY > ZX (Table S1). 
Fe concentrations in plaque on root surfaces increased by 2.6- to 3.9-fold from tillering to ear emergence stages, and then were maintained relatively stable to maturation stage (Fig. 1c). There were also significant differences $(P<0.05)$ in $\mathrm{Fe}$ concentrations in plaque among the cultivars at the same growth stage, and a similar trend in ROL was also observed (TableS2). A significant positive correlation between ROL amounts and $\mathrm{Fe}$ concentrations in $\mathrm{Fe}$ plaque of rice plants at six growth stages was also detected $\left(R^{2}=0.71, P<0.01\right)$ (Fig. 1d).

$\mathrm{THg}$ and $\mathrm{MeHg}$ concentrations in rice plants and in $\mathrm{Fe}$ plaque

Dynamic changes in $\mathrm{THg}$ and $\mathrm{MeHg}$ concentrations in straw, roots and Fe plaque of the four cultivars are presented in Fig. 2. Both $\mathrm{THg}$ and $\mathrm{MeHg}$ concentrations in straw tended to decline during the entire growth period (Fig. 2a, d). From tillering to maturation stages, $\mathrm{THg}$ and $\mathrm{MeHg}$ concentrations decreased by $0.94-$ to 1.4- and 3.2- to 6.7-fold, respectively. Furthermore, both $\mathrm{THg}$ and $\mathrm{MeHg}$ concentrations in straw exhibited significant differences $(P<0.05)$ among the cultivars, with the highest concentrations in ZX and the lowest in NJ35 (Tables S3, S4). THg concentrations in roots (Fig. 2b) increased by 1.2- to 4.0-fold from tillering to maturation stages, whereas $\mathrm{MeHg}$ concentrations in roots tissues (Fig. 2e) decreased by 1.5- to 2.2-fold during the entire growth period. $\mathrm{THg}$ concentrations in $\mathrm{Fe}$ plaque on roots (except for ZX) gradually increased from tillering to flowering (or grain-filling) stages, and then decreased up to the maturation stage, whereas they increased over the entire growth period for ZX (Fig. 2c). The dynamic change of $\mathrm{MeHg}$ concentrations in Fe plaque did not show any obvious trend.

Distributions of $\mathrm{THg}$ and $\mathrm{MeHg}$ in different plant components of the four rice cultivars during the entire growth cycle are presented in Fig. 3. In general, root tissues played the most dominant role in accumulating $\mathrm{THg}$ and increased gradually from tillering to maturation stages, whereas the aerial part accumulated the largest proportion of $\mathrm{MeHg}$. After the ear emergence stage, the $\% \mathrm{MeHg}$ in rice reproductive organs (panicle, grain and brown rice) increased sharply, reaching a maximum level at the maturation stage. Both $\mathrm{THg}$ and $\mathrm{MeHg}$ in $\mathrm{Fe}$ plaque were relatively lower than in the other parts of rice plants. However, the proportions of 



Fig. 1 Dynamic changes of ROL amounts (a), ROL rates (b) and $\mathrm{Fe}$ concentrations in Fe plaque (c), and relationship between ROL amounts and $\mathrm{Fe}$ concentrations in $\mathrm{Fe}$ plaque (d) for four rice

THg in Fe plaque of NJ35 and TY196 were higher than those of $\mathrm{HY}$ and $\mathrm{ZX}$.

Relationships analysis

Some interesting relationships were observed between ROL amounts, degrees of Fe plaque formation and $\mathrm{THg}$ concentrations in straw and in Fe plaque on root surface of the rice plants (Fig. 4). Significant negative correlations were found between ROL $\left(R^{2}=0.50, P<0.01\right), \mathrm{Fe}$ concentration in plaque $\left(R^{2}=0.60, P<0.01\right)$ and THg concentrations in straw, whereas there were significant positive correlations between ROL $\left(R^{2}=0.53, P<0.01\right)$, Fe concentration in plaque $\left(R^{2}=0.61, P<0.01\right)$ and THg concentrations in plaque at the six growth stages of the rice plants.

cultivars (TY196, HY, NJ35, ZX) at six growth stages (tillering, elongation, ear emergence, flowering, grain-filling and maturation stages). Data are means $\pm \mathrm{SE}(n=4)$

Correlations between ROL and $\mathrm{THg}$ concentrations in brown rice, and between $\mathrm{Fe}$ concentrations in plaque and $\mathrm{THg}$ concentrations in brown rice are presented in Fig. 5. Both ROL $\left(R^{2}=0.81, P<0.01\right)$ and Fe concentrations in plaque $\left(R^{2}=0.59, P<0.01\right)$ were negatively correlated with $\mathrm{THg}$ concentrations in brown rice of four cultivars at the maturation stage. However, there were no clear relationships between ROL, Fe concentrations in plaque and $\mathrm{MeHg}$ concentrations in different plant components of the four rice cultivars (data not shown).

\section{Discussion}

The THg concentrations in straw decreased steadily during the entire growth period, whereas in roots it 

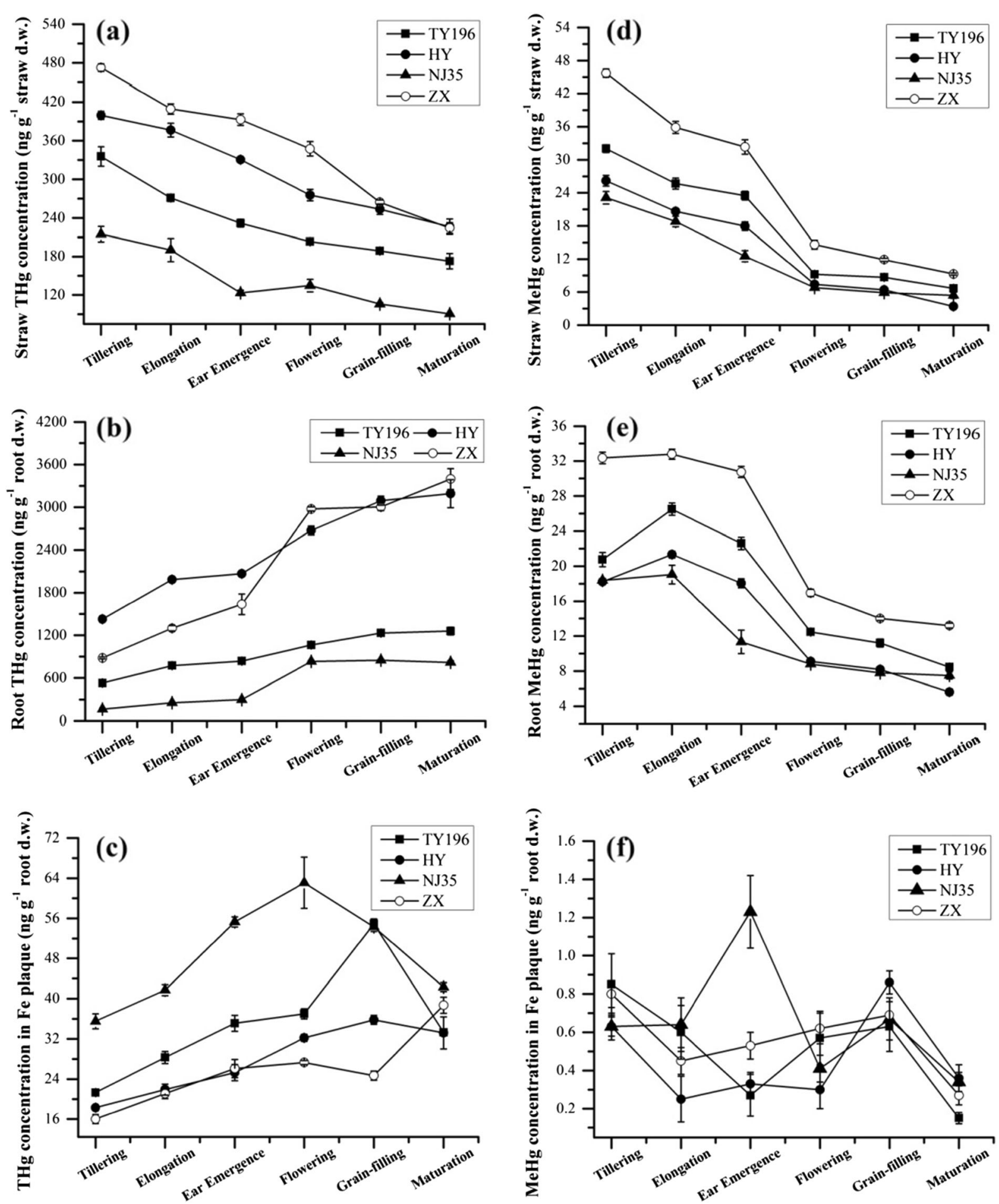

Fig. 2 Dynamic changes of $\mathrm{THg}(\mathbf{a}, \mathbf{b}, \mathbf{c})$ and $\mathrm{MeHg}(\mathbf{d}, \mathbf{e}, \mathbf{f})$ concentrations in straw, roots, and $\mathrm{Fe}$ plaque for four rice cultivars (TY196, HY, NJ35, ZX) at six growth stages (tillering, elongation,

ear emergence, flowering, grain-filling and maturation stages). Data are means $\pm \operatorname{SE}(n=4)$

plants have never been reported. Although the $\mathrm{THg}$ levels in straw showed a diminishing trend, it is knowledge, the temporal variations in $\mathrm{THg}$ levels in rice 

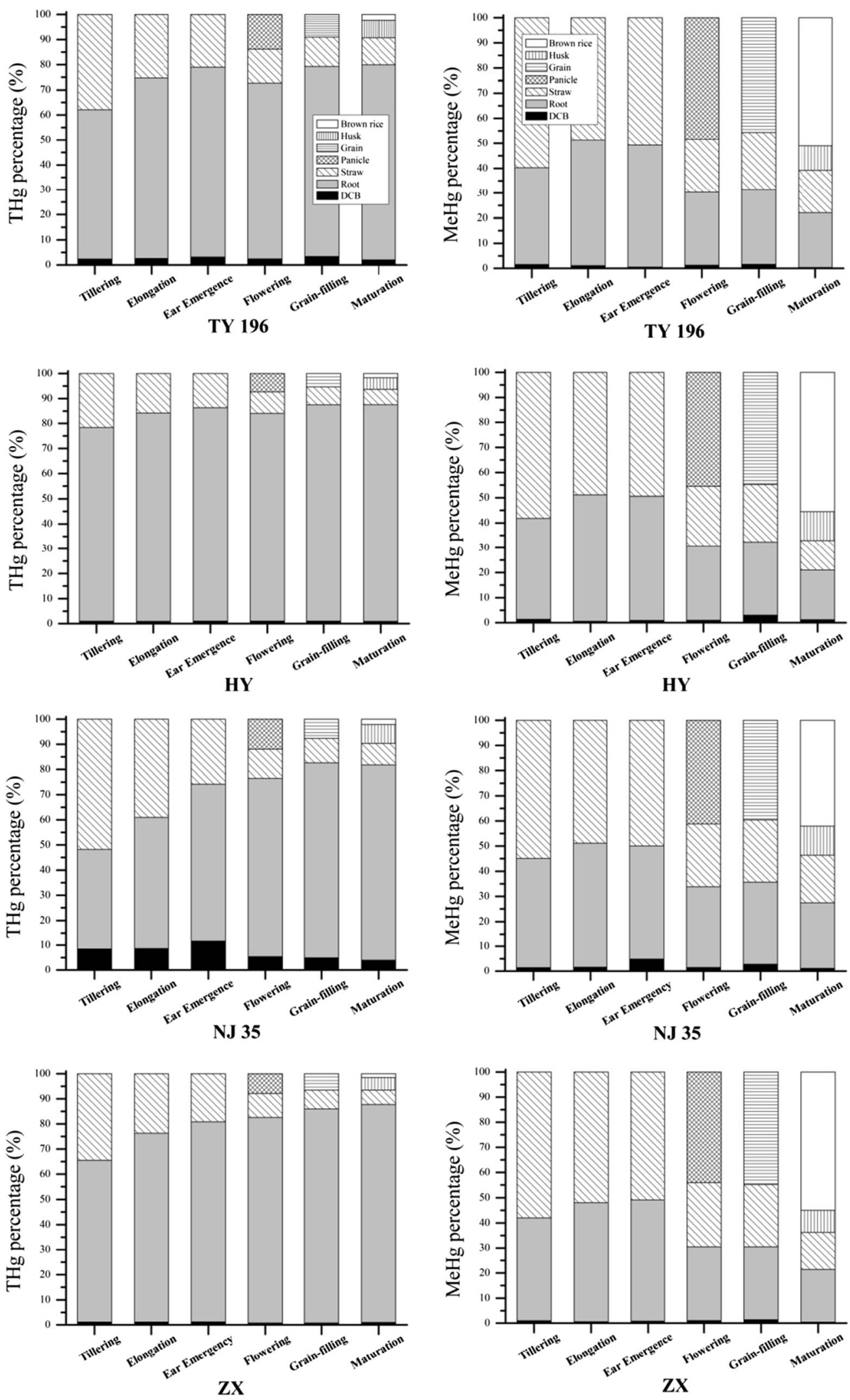
Fig. 3 Distribution of THg and $\mathrm{MeHg}$ in different components of four rice cultivars (TY196, HY, NJ35, ZX) at six growth stages (tillering, elongation, ear emergence, flowering, grain-filling and maturation stages)

premature to conclude that the 'pre-tillering' period may be the critical time for $\mathrm{Hg}$ ingress into the plant since the amount of THg accumulated in straw kept increasing during the entire growth period. The diminishing trend of THg concentration in straw may be due to the role of 'dilution', since the biomass of straw increased rapidly during the entire growth period. Both the concentration and proportion (Fig. 3) of $\mathrm{THg}$ in roots showed an increasing trend, suggesting that the entry of $\mathrm{THg}$ into the rice plant could be a persistent and continuous process, also indicating that roots play a dominant role


Fig. 4 Relationships between ROL amounts and THg concentrations in straw (a) and Fe plaque (c), and between $\mathrm{Fe}$ concentrations in $\mathrm{Fe}$ plaque and $\mathrm{THg}$ concentrations in straw (b) and Fe plaque in accumulating THg. Similar findings have been reported in previous studies on rice (Meng et al. 2010; Wang et al. 2014). It has also been reported that rice seed (brown rice) has the highest ability to accumulate $\mathrm{MeHg}$ compared to other tissues (Meng et al. 2010; Zhang et al. 2010a). Meng et al. (2011) also observed that both the concentration of $\mathrm{MeHg}$ and the mass of $\mathrm{MeHg}$ in stalks and leaves decreased sharply when the seed started to form, reaching a minimum level at rice harvest. The main reason for the decreasing trend of $\mathrm{MeHg}$ levels in roots and straw is that most of $\mathrm{MeHg}$ would be translocated into reproductive organs (panicle, grain and brown rice) when rice seed started to form. This is why both the concentration and proportion of $\mathrm{MeHg}$ in roots and straw decreased sharply after the earemergence stage. Our results from this study also
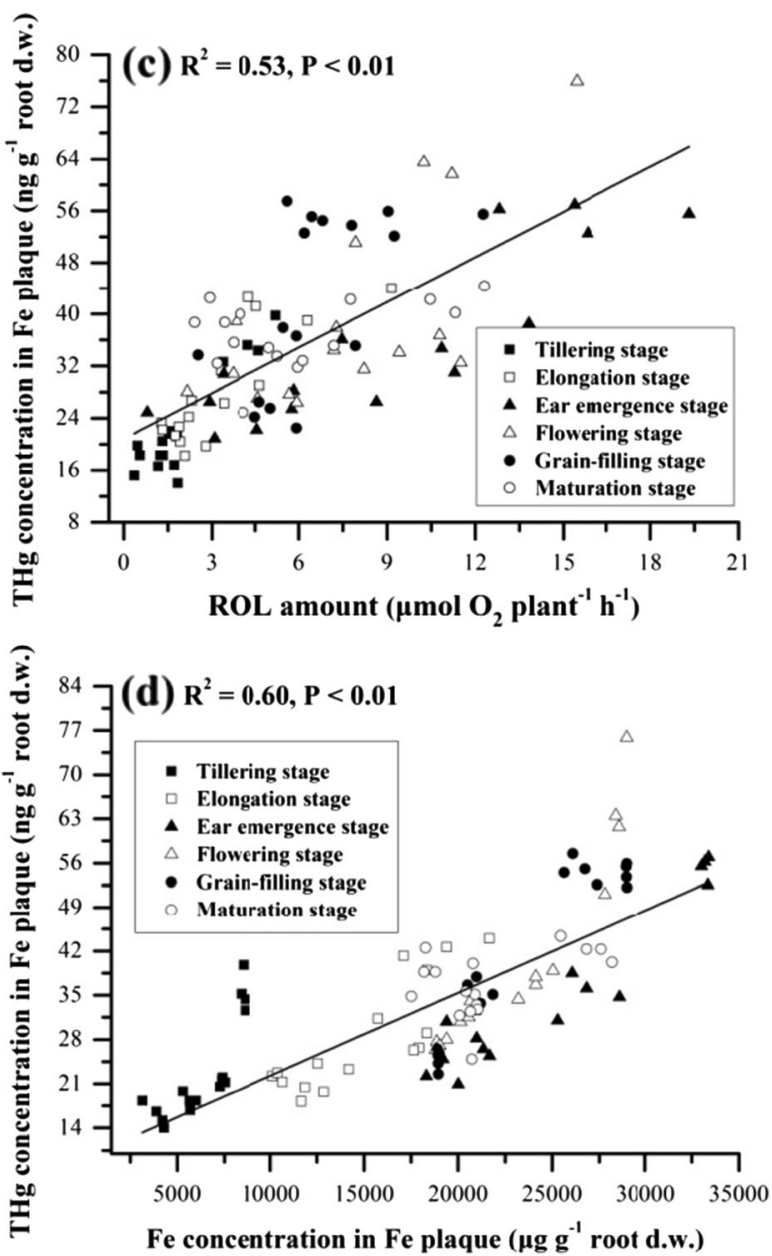

(d) for four rice cultivars (TY196, HY, NJ35, ZX) at six growth stages (tillering, elongation, ear emergence, flowering, grainfilling and maturation stages) 

mean values of ROL amounts (a) and $\mathrm{Fe}$ concentrations in $\mathrm{Fe}$ plaque (b) at six growth stages and $\mathrm{THg}$ concentrations in brown rice for four rice cultivars (TY196, HY, NJ35, ZX)
Fig. 5 Relationships between


suggested that reducing the translocation of $\mathrm{MeHg}$ into rice seeds during the ripening period could be an efficient way to decrease the accumulation of $\mathrm{MeHg}$ in brown rice.

ROL is an important process for wetland plants such as rice adapting them to waterlogged conditions (Armstrong and Armstrong 2005). In this study, ROL amounts increased as rice plants grew, reaching peak values during the reproductive period, and gradually decreasing up to the maturation stage. Similar results have been reported in a previous study (Wang et al. 2013). Furthermore, there were significant differences in ROLs among the rice cultivars (NJ35 $>$ TY196 $>$ HY $>$ ZX) at the same stage. It has been reported by other workers that ROL differs markedly not only between wetland species (Li et al. 2011; Yang et al. 2014) but also between cultivars of rice (Mei et al. 2009; Wang et al. 2011). Wetland species (or cultivars) with higher rates of $\mathrm{ROL}$ tend to form more $\mathrm{Fe}$ plaque on root surfaces and in the rhizosphere (Li et al. 2011; Yang et al. 2014). However, in the present study, only ROL amounts but not ROL rates, were significantly positively correlated with Fe concentrations in plaque on root surfaces (Fig. 1d). This result indicates that ROL amounts rather than ROL rates play a dominant role in affecting the formation of $\mathrm{Fe}$ plaque on root surfaces during the entire growth period of rice plants. It should also be noted that the $\mathrm{Fe}$ formation on root surfaces can be influenced by many abiotic factors such as the availability of soil Fe, temperature, $\mathrm{pH}, \mathrm{CO}_{2}$, soil permeability, etc. (Chen et al. 1980; St-Cyr and Crowder 1988), as well as biotic factors, including ROL and rhizosphere bacteria (St-Cyr and Crowder 1989; Chen et al. 2008). Mendelssohn et al. (1995) reported that ROL is the most 
important biotic factor controlling Fe plaque formation. Our study also suggests that the rice cultivars with higher ROL amounts released more $\mathrm{O}_{2}$ from roots during the reproductive phase of growth, and tend to deposit larger amounts of $\mathrm{Fe}$ on the root surfaces. It is also very likely that the increase in ROL with growth is due to the production of fine lateral roots. As the production of fine laterals during the entire growth period was not measured in this experiment, its effect was not clear. The significance of fine lateral root growth should be considered in further studies.

The significant negative correlations between ROL amounts and THg concentrations in straw (Fig. 4a) and brown rice (Fig. 5a) suggest that ROL had indirect effects on $\mathrm{THg}$ accumulation in above-ground tissues (straw, brown rice), and rice cultivars with higher ROL amounts tended to have a greater ability to inhibit $\mathrm{Hg}$ transfer and accumulation in above-ground parts than those with lower ROL amounts. ROL from roots may have important impacts in regulating $\mathrm{Hg}$ bioavailability in the rhizosphere and subsequently $\mathrm{Hg}$ accumulation in rice. It has been reported that the mobility and availability of many toxic metals to plants in wetland soils are often regulated by redox potential (Eh) and the associated rhizosphere $\mathrm{pH}$ (Gambrell et al. 1991). ROL from rice roots significantly changes $\mathrm{Eh}$ and $\mathrm{pH}$ in the rhizosphere (Mei et al. 2012). An increase in Eh in the rhizosphere by aerobic treatment could significantly reduce the THg in the soil solution (Peng et al. 2012) and $\mathrm{Hg}$ bioavailability (Wang et al. 2014) in rhizosphere soil, and ultimately decrease $\mathrm{THg}$ accumulation in brown rice.

The correlations in Fig. 4c, d suggest that ROL might also regulate $\mathrm{Hg}$ bioavailability by $\mathrm{Fe}$ plaque formation. However, the proportion of $\mathrm{THg}$ in Fe plaque was relatively lower than in tissues of rice plants, and the largest amount of THg was accumulated in root tissues (Fig. 3). This may imply that Fe plaque might not play a key role in reducing $\mathrm{Hg}$ transfer from roots to aboveground tissues and $\mathrm{Hg}$ accumulation in brown rice. The functions of $\mathrm{Fe}$ plaque on metal uptake may depend greatly on the amounts of $\mathrm{Fe} / \mathrm{Mn}$ deposition and metal bioavailability both on root surfaces and in the rhizosphere. Fe plaque could enhance $\mathrm{Zn}$ uptake by roots but might show a 'barrier' effect when large amounts of $\mathrm{Fe}$ are deposited on root surfaces (Otte et al. 1989; Jacob and Otte 2003). The effects of Fe plaque on Hg adsorption only focus on $\mathrm{Fe}$ and $\mathrm{Hg} / \mathrm{MeHg}$ on root surface in the present study. Yang et al. (2014) reported that the amounts of $\mathrm{Fe}, \mathrm{Mn}$ and $\mathrm{Zn}$ in the $\mathrm{Fe}$ plaque in the rhizosphere were larger than those on the root surfaces. It is possible that the adsorption of $\mathrm{Hg} / \mathrm{MeHg}$ in $\mathrm{Fe}$ plaque in the rhizosphere may be greater than that on the root surfaces but this needs further investigation. More in-depth studies on the role of ROL and Fe plaque on $\mathrm{Hg}$ and $\mathrm{MeHg}$ in both the rhizosphere and on root surfaces are required.

Both ROL amounts and the degree of Fe plaque formation on root surfaces showed no significant correlation with $\mathrm{MeHg}$ in plant tissues (brown rice, straw, roots) and in Fe plaque, which suggests that both ROL and $\mathrm{Fe}$ plaque had no clear effects on $\mathrm{MeHg}$ accumulation. Our data indicate that the effects of ROL and Fe plaque on $\mathrm{THg}$ and $\mathrm{MeHg}$ in soils and on uptake by rice plant were different and that $\mathrm{Fe}$ had a higher affinity for $\mathrm{THg}$ than for $\mathrm{MeHg}$. In a similar As study, Chen et al. (2005) found that Fe plaque enhanced As(III) but decreased As(V) uptake by rice. Liu et al. (2006) reported that arsenate was the predominant species of As in Fe plaque, whereas the organic species of As could hardly be detected in Fe plaque.

\section{Conclusions}

This study investigated the effects of ROL and Fe plaque on $\mathrm{Hg}$ and $\mathrm{MeHg}$ uptake and accumulation in rice plants. Our results demonstrated that ROL (amount and rate), $\mathrm{Fe}$ plaque formation, $\mathrm{THg}$ and $\mathrm{MeHg}$ in tissues of rice plants showed great variations over the six growth stages. Rice cultivars with higher ROL amounts tended to have higher degrees of Fe formation on root surfaces and lower THg in straw and brown rice, which suggests that ROL has strong effects on $\mathrm{THg}$ uptake and accumulation. However, ROL and Fe plaque have no obvious effects on $\mathrm{MeHg}$ accumulation. The present study increases our understanding of the dynamic changes of ROL, Fe plaque formation and their roles in accumulation of THg and $\mathrm{MeHg}$ over the life cycle of the rice plant. The effects of ROL on microbial composition and abundance, Fe plaque formation on root surfaces and in the rhizosphere, and their relationships with $\mathrm{THg} / \mathrm{MeHg}$ accumulation under field conditions all require further investigation.

Acknowledgments This work was funded by the National Natural Science Foundation of China (30770417, 31070450), the National Basic Research Program of China (2013CB430004), 
and the National ' 863 ' project of China (2012AA061510, 2013AA062609). We thank Prof. A.J.M. Baker (The Universities of Melbourne and Queensland, Australia) for help in the initial preparation and improvement of this paper.

\section{References}

Armstrong J, Armstrong W (2005) Rice: sulfide-induced barriers to root radial oxygen loss, $\mathrm{Fe}^{2+}$ and water uptake, and lateral root emergence. Ann Bot-Lond 96:625-638

Aulakh MS, Wassmann R, Bueno C, Kreuzwieser J, Rennenberg H (2001) Characterization of root exudates at different growth stages of ten rice (Oryza sativa L.) cultivars. Plant Biol 3:139-148

Blute NK, Brabander DJ, Hemond HF, Sutton SR, Newville MG, Rivers ML (2004) Arsenic sequestration by ferric iron plaque on cattail roots. Environ Sci Technol 38:6074-6077

Chen CC, Dixon JB, Turner FT (1980) Iron coatings on rice roots: mineralogy and quantity influencing factors. Soil Sci Soc Am J 44:635-639

Chen Z, Zhu YG, Liu WJ, Meharg AA (2005) Direct evidence showing the effect of root surface iron plaque on arsenite and arsenate uptake into rice (Oryza sativa) roots. New Phytol 165:91-97

Chen XP, Kong WD, He JZ, Liu WJ, Smith SE, Smith FA, Zhu YG (2008) Do water regimes affect iron-plaque formation and microbial communities in the rhizosphere of paddy rice? J Plant Nutr Soil Sci 171:193-199

Cheng H, Wang MY, Wong MH, Ye ZH (2014) Does radial oxygen loss and iron plaque formation on roots alter $\mathrm{Cd}$ and $\mathrm{Pb}$ uptake and distribution in rice plant tissues? Plant Soil 375:137-148

Clarkson TW (1993) Mercury: major issues in environmental health. Environ Health Perspect 100:31-38

Colmer TD (2003) Long-distance transport of gases in plants: a perspective on internal aeration and radial oxygen loss from roots. Plant Cell Environ 26:17-36

Feng XB, Li P, Qiu GL, Wang S, Li GH, Shang LH, Meng B, Jiang HM, Bai WY, Li ZG, Fu XW (2008) Human exposure to methylmercury through rice intake in mercury mining areas, Guizhou Province, China. Environ Sci Technol 42: 326-332

Gambrell RP, Wiesepape JB, Patrick WH, Duff MC (1991) The effects of $\mathrm{pH}$, redox, and salinity on metal release from a contaminated sediment. Water Air Soil Pollut 57-58:359-367

Garnier JM, Travassac F, Lenoble V, Rose J, Zheng Y, Hossain MS, Chowdhury SH, Biswas AK, Ahmed KM, Cheng Z, van Geen A (2010) Temporal variations in arsenic uptake by rice plants in Bangladesh: the role of iron plaque in paddy fields irrigated with groundwater. Sci Total Environ 408:4185-4193

Hansel CM, Fendorf S, Sutton S, Newville M (2001) Characterization of Fe plaque and associated metals on the roots of mine-waste impacted aquatic plants. Environ Sci Technol 35:3863-3868

ISO (2005) Soil quality - Determination of pH (ISO 10390:2005)

Jacob DL, Otte ML (2003) Conflicting process in the wetland plant rhizosphere: metal retention or mobilization? Water Air Soil Pollut 3:91-104
Jiang GB, Shi JB, Feng XB (2006) Mercury pollution in China. Environ Sci Technol 40:3672-3678

Kludze HK, DeLaune RD, Patrick WH (1994) A colorimetric method for assaying dissolved oxygen loss from containergrown rice roots. Agron J 60:616-621

Li P, Feng X, Qiu G, Shang L, Wang SF (2008) Mercury exposure in the population from Wuchuan mercury mining area, Guizhou, China. Sci Total Environ 395:72-79

Li H, Ye ZH, Wei ZJ, Wong MH (2011) Root porosity and radial oxygen loss related to arsenic tolerance and uptake in wetland plants. Environ Pollut 159:30-37

Li B, Shi JB, Wang X, Meng M, Huang L, Qi XL, He B, Ye ZH (2013) Variations and constancy of mercury and methylmercury accumulation in rice grown at contaminated paddy field sites in three provinces of China. Environ Pollut 181:91-97

Liu WJ, Zhu YG, Hu Y, Williams PN, Gault AG, Meharg AA, Charnock JM, Smith FA (2006) Arsenic sequestration in iron plaque, its accumulation and speciation in mature rice plants (Oryza sativa L.). Environ Sci Technol 40:5730-5736

Macfie SM, Crowder AA (1987) Soil factors influencing ferric hydroxide plaque formation on roots of Typha latifolia L. Plant Soil 102:177-184

Mehrotra AS, Sedlak DL (2005) Decrease in net mercury methylation rates following iron amendment to anoxic wetland sediment slurries. Environ Sci Technol 39:2564-2570

Mehrotra AS, Horne AJ, Sedlak DL (2003) Reduction of net mercury methylation by iron in Desulfobulbus propionicus (1pr3) cultures: implications for engineered wetlands. Environ Sci Technol 37:3018-3023

Mei XQ, Ye ZH, Wong MH (2009) The relationship of root porosity and radial oxygen loss on arsenic tolerance and uptake in rice grains and straw. Environ Pollut 157:2550-2557

Mei XQ, Wong MH, Yang Y, Dong HY, Qiu RL, Ye ZH (2012) The effects of radial oxygen loss on arsenic tolerance and uptake in rice and on its rhizosphere. Environ Pollut 165: 109-117

Mendelssohn IA, Kleiss BA, Wakeley JS (1995) Factors controlling the formation of oxidized root channels: a review. Wetlands 15:37-46

Meng B, Feng XB, Qiu GL, Cai Y, Wang DY, Li P, Shang LH, Sommar J (2010) Distribution patterns of inorganic mercury and methylmercury in tissues of rice (Oryza sativa L.) plants and possible bioaccumulation pathways. J Agric Food Chem 58:4951-4958

Meng B, Feng XB, Qiu GL, Liang P, Li P, Chen CX, Shang LH (2011) The process of methylmercury accumulation in rice (Oryza sativa L.). Environ Sci Technol 45:2711-2717

Nanzyo M, Yaginuma H, Sasaki K, Ito K, Aikawa Y, Kanno H, Takahashi T (2010) Identification of vivianite formed on the roots of paddy rice grown in pots. Soil Sci Plant Nutr 56:376381

Otte ML, Rozema J, Koster L, Haarsma MS, Broekman RA (1989) Iron plaque on roots of Aster tripolium L.: interaction with zinc uptake. New Phytol 111:309-317

Peng XY, Liu FJ, Wang WX, Ye ZH (2012) Reducing total mercury and methylmercury accumulation in rice grains through water management and deliberate selection of rice cultivars. Environ Pollut 162:202-208

St-Cyr L, Crowder AA (1988) Iron oxide deposits on the roots of Phragmites australis related to the iron bound to carbonates in the soil. J Plant Nutr 11:1253-1261 
St-Cyr L, Crowder AA (1989) Factors affecting iron plaque on the roots of Phragmites australis (Cav.) Trin. ex Steudel. Plant Soil 116:85-93

Taylor GJ, Crowder AA (1983) Use of the DCB technique for extraction of hydrous iron oxides from roots of wetland plants. Am J Bot 70:1254-1257

Taylor GJ, Crowder AA, Rodden R (1984) Formation and morphology of an iron plaque on the roots of Typha latifolia $\mathrm{L}$. grown in solution culture. Am J Bot 71:666-675

Ullrich SM, Tanton TW, Abdrashitova SA (2001) Mercury in the aquatic environment: a review of factors affecting methylation. Crit Rev Environ Sci Technol 31:241-293

USEPA (2001) Method 1630: methylmercury in water by distillation, aqueous ethylation, purge and trap, and CVAFS; EPA821-R-01-020; Washington, DC

Wang MY, Chen AK, Wong MH, Qiu RL, Cheng H, Ye ZH (2011) Cadmium accumulation in and tolerance of rice (Oryza sativa L.) varieties with different rates of radial oxygen loss. Environ Pollut 159:1730-1736

Wang X, Yao HX, Wong MH, Ye ZH (2013) Dynamic changes in radial oxygen loss and iron plaque formation and their effects on Cd and As accumulation in rice (Oryza sativa L.). Environ Geochem Health 35:779-788
Wang X, Ye ZH, Li B, Huang LN, Meng M, Shi JB, Jiang GB (2014) Growing rice aerobically markedly decreases mercury accumulation by reducing both $\mathrm{Hg}$ bioavailability and the production of MeHg. Environ Sci Technol

Yang JX, Tam NFY, Ye ZH (2014) Root porosity, radial oxygen loss and iron plaque on roots of wetland plants in relation to zinc tolerance and accumulation. Plant Soil 374: 815-828

Ye ZH, Baker AJM, Wong MH, Willis AJ (1997) Copper and nickel uptake, accumulation and tolerance in Typha latifolia with and without iron plaque on the root surface. New Phytol 136:481-488

Zhang H, Feng XB, Larssen T, Qiu GL, Vogt RD (2010a) In inland China, rice, rather than fish, is the major pathway for methylmercury exposure. Environ Health Perspect 118:11831188

Zhang H, Feng XB, Larssen T, Shang L, Li P (2010b) Bioaccumulation of methylmercury versus inorganic mercury in rice (Oryza sativa L.) grain. Environ Sci Technol 44: 4499-4504

Zhang CH, Ge Y, Yao H, Chen X, Hu MK (2012) Iron oxidationreduction and its impacts on cadmium bioavailability in paddy soils: a review. Front Env Sci Eng 6:509-517 